\title{
Mobile apps as government communication media in urban public services: case study - the usage of Qlue application by Jakarta Provincial Government
}

\author{
M. Shendy Adam Firdaus ${ }^{1}$ Irwansyah $^{2}$ \& K. Djaja ${ }^{1}$ \\ ${ }^{1}$ Urban Studies Graduate Program Universitas Indonesia, Indonesia \\ ${ }^{2}$ Communication Studies Graduate Program, \\ Universitas Indonesia, Indonesia
}

\begin{abstract}
The fast-paced development of internet technology and the infiltration of mobile communication devices have produced the 'always on' society phenomenon. At the same time, the concept of 'smart city' considered to be relevant to overcoming plenty of challenges that 21 st century urban areas face. The utilization of technology by means of 'mobile government' ('m-government') is believed to be competent to bridge public needs with public service that government provided. One form of the 'm-government' is the usage of mobile application (mobile app) as a medium of government communication.

This research is undertaken with a case study of Qlue mobile app organized by the Provincial Government of DKI Jakarta. The qualitative methods used are interviews and observations to validate this research. The vital discovery of this research is that Qlue comes up as the tool for public-oriented government communication. Qlue has been operated not only for running the communication function of government, which becomes the media for government socialization; but also to become the channel of public needs aspiration delivery. In the context of good governance, the use of mobile apps has been contributing to implement the principles of participation, equality, and accountability.

Keywords: government communication, mobile apps, smart city, smart governance.
\end{abstract}




\section{Introduction}

Increasing internet penetration occurs not only in developed countries, but also in developing countries. Data from APJII [1] shows that in 2014 internet penetration in Indonesia had reached the number of 88.1 million users or about $34.9 \%$ of population. In general, urban areas have a greater trend to use the internet. Jakarta turns out to be the top city with internet penetration with $56 \%$ of its population using the internet [1].

In line with that, the growth of information and communication technology (ICT) is rapidly expanding. Nowadays, the smart phone functions not only to make calls and send messages, but also performs various activities with the support of a mobile app. McLuhan [2] stated that basically human culture has been influenced by technology. That is what is currently happening to society, in urban areas particularly. To illustrate that, Jakarta residents now have become familiar with mobile apps to order ojek (taxibike) and taxi (Go-Jek, Grab, Uber, etc.), to purchase hotel vouchers and flights (Traveloka, Trivago, Pegipegi, etc.), to buy food (Go-Food, FoodPanda, etc.), and to shop for various items (Lazada, Bukalapak, Tokopedia, etc.).

Mobile apps offer opportunities for both the public and private sector to provide better public services. Mobile apps are designed to be suitable for mobile devices and become the core of 'm-government' which can be accessed anytime and anywhere [3]. Mobile apps of public services in urban areas is one of the indicators of the ongoing evolution, which is "ubiquitous government" [4] or "smart government".

Digital era has indeed changed the principle aspects of human life including government, especially the relationship between government and public. In order to create the smart city, smart government needs the approach of more advanced mindset and point of view in utilizing and integrating information, technology, and innovation. That approach is applied not only for government activities or internal affairs, but also for public services and society empowerment [5]. However, the experience in many cities indicates that excellent progress will not be begun without significant transformation in government practice, which means bureaucracy structure needs to be adapted to accommodate the new technology and its usage [6].

DKI Jakarta Provincial Government presently commits to strive hard to become smart city. One of the ways is to utilize Qlue, mobile app created by local developer, as a participative communication tool especially for accommodating all reports from the Jakarta residents. Rather than stopping at the point of having accurate information from public, the smart city will think more of having advantages from the data. Realizing that, the Provincial Government of DKI Jakarta keeps innovating to find the best way to respond the reports from all Jakarta citizens as quickly as possible.

According to previous studies, it is discovered that only a little research has focused on how to adopt a mobile app as a government communication tool from the government point of view. Meanwhile, from a public perspective, it is no doubt that public has been ready enough to make use of technology. The 
research from Hand and Ching [7] in Phoenix metropolitan area shows that the use of social media by local government is promising the rising of public involvement. Another research conducted by Sadat [8] who studied about LAPOR! (Layanan Aspirasi dan Pengaduan Online Rakyat), the 'm-government' innovation from the Indonesian Government, believed that the public will benefit from LAPOR! because of its amenities, time and cost efficiency, accessible to communicate and participate in decision-making and personalization.

Therefore, this research tends to understand how the adoption of contemporary communication technology using a mobile app as a medium of government communication within the framework of 'm-government'. To be more specific, this research is trying to answer the main question: "How is Qlue mobile app becoming the medium for public-oriented government communication in DKI Jakarta Provincial Government public services?"

\section{Theoretical background}

\subsection{Smart city and smart government}

The increasing urbanization trend at the beginning of 21 st century has made governments around the world face new challenges, such as sustainable development, energy and the environment, security, and public services. The city has become a complex social ecosystem. The implementation ICT is an important consideration in solving economic, social, and environmental problems being faced in cities $[9,10]$.

In this framework, the concept of smart city has won the attention. Although there is no general consensus on the smart city concept, basically the idea of smart city is rooted from the connection of human capital, social capital, and ICT infrastructure to produce greater and more sustainable economic development as well as a better quality of life [9]. Moreover, another scholar argues that smart city is the linkages between technology innovation, organization and managerial innovation, and policy innovation [11].

Referring to the European standard, there are six substantial points in classifying a smart city, including: economy, people, living, governance, environment, and mobility [12]. Undoubtedly, technology has been playing a big role in order to create a more intelligent city. Nevertheless, how the city uses technology for a specific purpose and how the dependency on technology is also determined by other components, such as the capabilities of city management and the dynamics of urban policy. The innovation of the public sector and the local government role is fundamental for smart city initiatives [13].

Some scholars expressed that we have exceeded the shifting era from "government" to "governance" $[14,15]$. However, what do those two concepts actually mean? Hambleton and Gross [16] imposed the limit of those concepts. "Government" refers to the formal institution of the nation, while "Governance" encompasses the government itself added with integration, negotiation, and influence from other actors, such as the private sector and civil society. In other 
words, government limited to institutional matter, whereas governance is more likely on management system aspects among the stakeholders.

The derivative of smart governance involves participation in decision-making, social and public services, open government etc. [17]. In terms of making the smarter city, smart government must have an advanced mindset and perspective to integrate information, technology, and innovation not only for administration activities but also for running public services and citizen involvement [5]. Generally, the local government uses an online platform to increase public participation, the most popular one being a report website, where people can make a report, complaint, and ask for any information related to public services [17].

Electronic government and mobile government which have continued to grow in the last two decades are examples of innovation in the public sector. The use of digital technology is not only transforming the internal government operational, but also changing the external relationship between the public and other stakeholders. The new generation of tools and applications now has emerged, usually called Government 2.0, which facilitates public active participation through social media [18].

\subsection{Public sector communication}

The keyword for smart city is communication [19], including the mutual relationship between energy, resources, information system, service monitoring and control, and participation. When communication becomes the keyword for the smart city, it is necessary for the city to get along with the externals. Therefore, local government needs an active involvement and participation from civil societies.

Public sector communication is the coherence of communication and government concept. Hasan [20] defined government communication as the delivery of ideas, programs, and concepts from the government to the public in order to achieve the national goals. In other words, government is assumed to be the communicator and the public is considered to be the communicant. In reverse, in other situations the public can have a position of ideas initiator while the government plays a role in monitoring what people want.

Government communication can also be interpreted as all activities at public sector institutions with the objective of information delivering and sharing, mainly to present and explain government decisions and actions, to promote legitimacy of intervention, to preserve recognized values, as well as to support maintaining social bond [21].

Pasquier [21] differentiated two functions of government communication based on dominancy: (1) core function, including to serve information and explanation to public and to socialize the good values; (2) supporting function, including orientation of the citizens and residents, showing responses, and contributing to social bond.

When government communication is limited to the existence of leaflet and press networking, then the government organization itself is no more than "communication machine" [22]. The development of contemporary 
communication technology has brought changes in government communication channel. The link between new media and government communication plays a substantial role in understanding the current challenges faced by government bureaucracy [23].

\subsection{Mobile government}

Mobile government ('m-government') is widely accepted as a derivative of electronic government ('e-government') which opens the opportunities for public to be more involved, and also increases the fundamental function of government, particularly in providing public service to the citizens $[24,25]$. The scholars are convinced that the existence of 'm-government' will not substitute 'egovernment' but will be complementary [24, 26].

In general, 'm-government' is defined as the implementation of a wireless mobile communication technology in the administration activities, such as personal digital assistant (PDA), smart phone, and mobile app. Mobility and flexibility are the eminent characters of 'm-government'. As Nava and Davila [27] emphasized, the general purpose of 'm-government' is to strengthen the mobility value (including personalization, comfort, affordability, etc.) and to integrate all the 'e-government' services by means of wireless internet which can be accessed anytime and anywhere.

'M-government' can be classified into four categories according to whom the service is given. The service and mobile app are mostly used to mediate government with public (G2C), yet the interaction between government with business (G2B), government with government (G2G), and government with employees (G2E) are also able to utilize the mobile technology.

Zalesak [28] also distinguished 'm-government' into four categories: ' $\mathrm{m}$ Communication', 'm-Services', 'm-Democracy', and 'm-Administration'. In the meantime, OECD and ITU [29] divided 'm-Government' into four other categories, which are education and information service (push services), interactive services, transactional services, and community involvement services in governance.

The development of mobile devices and mobile applications recently is creating new opportunities for public sector, especially in the improvement of 'm-government'. According to Ganapati [3], there are two types of applications commonly used by government. First is 'enterprise-focused apps', usually used for internal affairs inside the government organization. Second is 'citizenoriented apps', applied for external affairs which can be accessed by anyone who needs public service. Mobile app is easy to be operated by any level of government, from the national/ federal, province/ state, until local/ regional.

\section{Methodology}

This research is engaged with an 'exploratory research' approach to explain how the mobile app is used in government communication in the context of urban public services and how the organizational adaptation in the bureaucracy 
implements it. 'Exploratory research' is used to determine a new topic or issue where the data is still hard to find [30]. In this research, the purposed phenomenon is the use of mobile app in government operational (mgovernment).

Particularly, this research applied a depth-interview technique in the data gathering. The researchers also used observation technique by taking the field studies in two kelurahan (sub district) as the locus of observation (Pulo and Duri Kepa Sub District), along with Qlue application virtual room to monitor how the interaction happened in that social media.

The research design categorized as a case study, determined by its analysis unit (Yin [31]). Analysis unit is the unit that will become the focus of a research. Analysis unit can be individual, venue, and activities. This research analysis unit is the users of Qlue mobile app among the DKI Jakarta Provincial Government officers. In accordance with that analysis unit, the subject of the research is the dynamics of the implementation and the adaptation of bureaucrats to Qlue mobile app as a participative government communication media. The subject who will be the informants of this research is the officers of DKI Jakarta Provincial Government in sub district level as the ones who influenced the most by the existence of Qlue mobile app.

After the data collecting process, the next step is data analysis and tabulation. This research is using qualitative technique data analysis from the Miles and Huberman model [32]. There are three stages in that model, starting from data reduction, data display, up to conclusion drawing/verification.

\section{Results}

As the capital city of the country, the central government, the economic and business center, and the other cognomens attached, Jakarta has been brought forth the rapidly development of city and society. Jakarta is often called a melting pot or the meeting point of various cultures from all around Indonesia. This condition has formed the heterogeneous society, including race, religions, culture, to socio-economic stratification. The Provincial Government of DKI Jakarta is required to provide non-discriminatory service as well as to be able to absorb the public aspirations.

Before Qlue existed, DKI Jakarta Provincial Government had already possessed several aspiration channels to accommodate reports, complaints, and suggestions from public. Based on the classification provided in the official report website, that is Respon Opini Publik (ROP)/Public Opinion Response (POR), there are 13 aspiration channels for Jakarta residents, beginning with the most conventional ones (face to face, letter, newspapers scrapbook) to the computer remediation (email, Facebook and Twitter). The specific character from external communication applied in those 13 channels is that they are all centralized at a provincial level, namely through Public Relations, Informatics, and Communication Agency.

Despite already having quite a lot of channels aspirations, DKI Jakarta Provincial Government continues trying to search for the easier and more 
practical way to collect public aspirations. The technology development becomes the determination to keep finding the innovation. The appearance of android technology has made an important starting point for DKI Jakarta Provincial Government to perform mobile government. The increasing mobility of citizens, facilitated by tools, makes it easier for people to access public services.

The core function of government communication is emphasized more on the delivery of information to the public, giving public explanation in order to get support from them, keeping the good values and promoting responsible behaviors [21]. Kleinhans et al. [33] stated that many local governments around the world using social media and other devices with three communication strategies: representation, civil society involvement, network building. However, a number of researches illustrated that government ordinarily focus only on one aspect: representation, which implements 'push strategies' or one-way communication [34]. According to that literature, it is known that one waycommunication (government to public) has always been the priority.

On the contrary, this research has found a different invention. Qlue application used by DKI Jakarta Provincial Government has been focusing on providing what people need, which is according to Pasquier [21] actually the only supporting function of government besides the one way-communication as a usual operation. Different from Twitter and Facebook, where DKI Jakarta Provincial Government has active accounts in publishing, much official information about government, what has been happening in Qlue is converse. In Qlue, the active accounts are from the public instead, in which they send reports to be responded by DKI Jakarta Provincial Government officers. This discovery has also affirmed the opinion from Ganapati [3] that the special character from mobile app implemented by government is indeed 'citizen oriented'.

Two way-interactive communications is very substantial in the management of local government. Interactive city is the one giving participation and collaboration spaces, where citizens are not only becoming the contributor [11]. Information obtained by two way-communications can be benefited for raising the quality of public services in terms of responding to public needs and preferences [35]. Study form Green Watch Project has proved that citizens are able to be the accurate data collectors [36].

The key character of government communication after the adoption of Qlue is public needs-oriented. The advantages of Qlue in government communication are directed more to gain information from public about what they need, rather than to give information from government to public. The officers of DKI Jakarta Provincial Government are becoming aware of the importance of citizen participation in government. A number of the informants of the research reveal how Qlue is ready to accommodate two way-communications between the public and government.

As the expression coming from the informants, it is known that public needs reported via Qlue - have become the priority of DKI Jakarta Provincial Government. Therefore, the civil society's involvement in governance process is going up day by day. At least, the public now already have awareness on the surroundings and are eager to report to provincial government. Besides sending 
the reports, the public recently have a vehicle for dialogue by way of availabled features in Qlue mobile app. The involvement of civil society makes it more possible to grow the sense of belonging from the public to the city, to increase the attention of local government related to the public needs, and in the end to transform the relationship form between government and public [11,37].

It cannot be denied that the excellence of ' $m$-government' application is on its mobility. The public can make reports anytime and anywhere. From the standpoint of the public, anybody can make a report. Therefore, it is highly possible for the sub district to gain the reports from the non-residents in related areas. Indeed, the reports are perhaps coming from non-Jakarta residents who stay in the city just to go to work.

The outcome of this research is parallel to what Nava and Davila [27] proposed that mobility of ' $m$-government' makes it possible for broader access for the public. Whereas Ganapati [3] stated that the higher the smart phone penetration the wider access for the public to reach government, which is very much different if public services still rely on web based 'e-government' that should be accessed by computer.

The fact that whoever can use Qlue has been showing the presence of equal strata in society, which is also one of the basic principles of good governance. Goldsmith and Crawford [6] explained, "an important part of the digital revolution in governance will be the use of those tools by ordinary people to engage their government in ways that were unimaginable only a few years ego."

Anonymity appears to be the notable character of mobile app-based government communication. The Qlue users ordinarily do not put the original identity as an account. As a result, people are comfortable to use this application to report any complaint without being worried about being intimidated for what they have already reported. Comfort is the significant factor in adopting mobile government, as it is approved by previous research [27, 38]. On the other hand, anonymity also comes up with a specific problem. The informants of this research coming from sub district claim that many anonymous users are using Qlue irresponsibility.

Besides opening the opportunities as wide as possible to anyone to make a report, Qlue also does not restrict the reported topic. Anything related to public services can be reported, yet the users still need to choose the category. At present, Qlue application owns 24 topics or categories to be defined (see Figure 1). Nevertheless, there are still people reporting problems out of those 24 topics. This feature has become a solution to the highly various problems from the different perspectives that people have. One of the supremacies of a mobile government application is its personalization and precision in reaching the target $[39,40]$.

As mentioned in the previous section, other government communications besides Qlue are mostly centralized at the provincial level. Meanwhile, Qlue is decentralized at the sub district. By using 'location based services', each report is classified automatically based on the sub district area. Therefore, the sub district officers must use and monitor the Qlue application whether there are reports from the public in their area or not. 


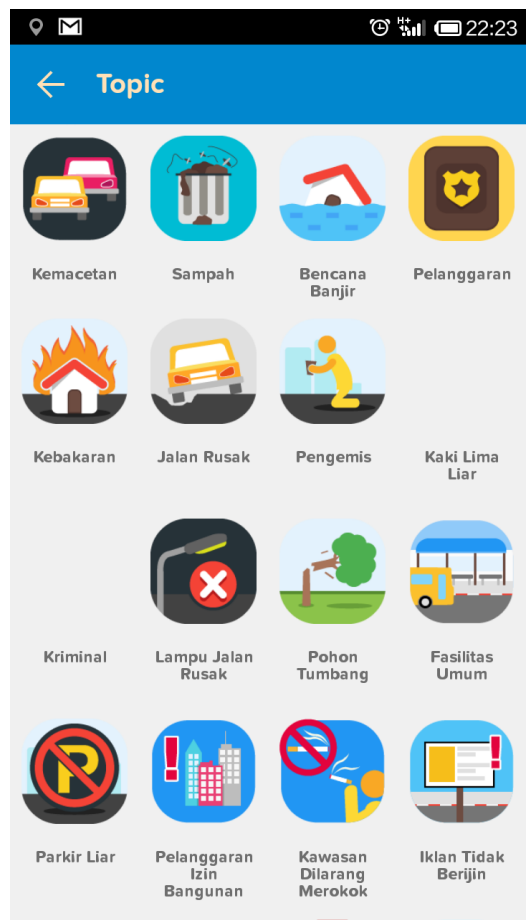

Figure 1: The options of public reports topic in Qlue.

Qlue can also be used as government internal communication media. The sub district officers as the "person in charge" in the area will forward the information to the related technical unit. For instance, the coordination can be carried out automatically through a mobile app by mentioning the account name of the purposed-officer/functionary (as shown in Figure 2), where Lurah/sub district head (@LurahPulo) directly coordinated with the personnel from the technical unit who handles landscape gardening (@TamkamJS).

The growing relationship, both externally (with the public) and internally (inter-personnel) tend to be impersonal since there is no direct contact or face to face. This condition is fit to minimize the abuse of authority by the apparatus to the public.

The advantage of using technology in government communication, especially in terms of public services, is its capability to automatically detect the location of the report. Moreover, by developing a specific application, the needs of the institution can be adapted. In fact, it cannot happen when the tool is only the common social media like Facebook and Twitter.

This research also found out that the utilization of ICT will finally produce efficiency in time. With the decentralized authorization, government can respond every report from public as fast as possible. The collaboration with the private sector in making the allocation of budget needs of the application development also eases the government load. Hallin and Lundevall [41] declared that a city 
implementing mobile government will gain benefits, such as simplification of routines, minimization of administration, money and time efficiency, and easiness of public access to contribute to a better environment.

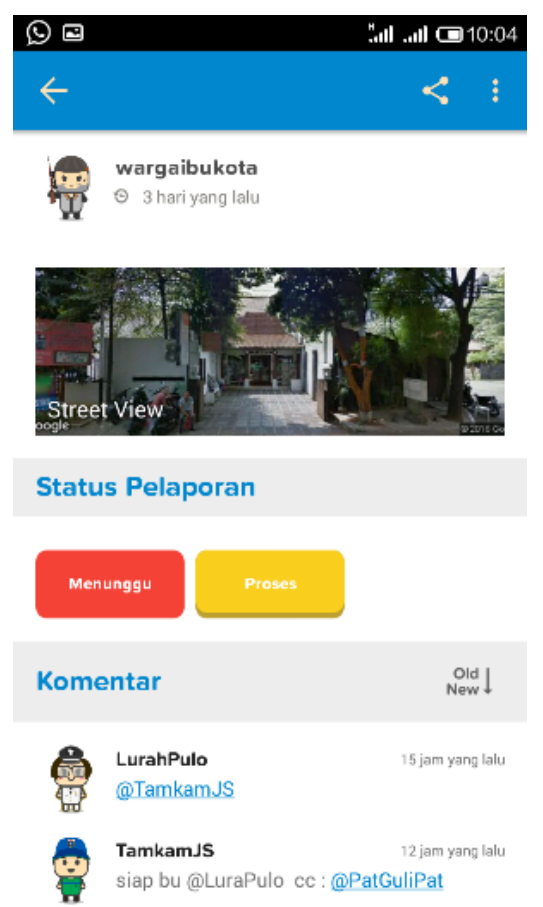

Figure 2: Qlue can be used as the government internal communication media.

\section{Conclusion}

Government in smart city plays a vital role, which is optimizing ICT function to create interactive, participatory, and information-based surroundings [42, 43], to increase public service quality [44], and to operate administrative function through improved collaboration inter-department and with the communities [42]. The new wave of "smart city" context evokes a wider discussion of government decentralization in the information era [45], as well as push government to think about a new way to communicate, interact, and public services delivery [12].

The result of this research has indicated that the implementation of Qlue by DKI Jakarta Provincial Government is more oriented to attract public aspirations and respond them instead of using it as a one way-communication from government to public. This finding is the antithesis of Pasquier's opinion [21], which claimed that the core function of government communication is to deliver the public information and policy from government to public, while the 
orientation to public and responding to them only considered as an additional function.

Several characteristics of a mobile app as a public-oriented government communication media are: its focus on public needs, that it is accessible for anyone, there is a confidential guarantee for its anonymous option, unlimited topic for any public services report, post-bureaucratic model of government communication, and efficiency.

\section{References}

[1] Asosiasi Penyelenggara Jasa Internet Indonesia (APJII). Profil Pengguna Internet Indonesia 2014. APJII: Jakarta, pp. 9-11, 2015.

[2] McLuhan, M. Understanding Media: The Extensions of man. McGraw Hill Book Company: New York, 1964.

[3] Ganapati, S. Using Mobile Apps in Government. IBM Center for The Business of Government: Washington DC, 2015.

[4] Belanger, F., Carter, K.D. \& Schaupp, L.C. U-government: A framework for the evolution of e-government. Electronic Government: $A n$ International Journal, 2(4), pp. 426-445, 2005.

[5] Gil-Garcia, J.R., Pardo, T.A., Nam, T. (ed.). Smarter as the New Urban Agenda A Comprehensive View of the 21st Century City. Public Administration and Information Technology Vol. 11, Springer: New York, 2016.

[6] Goldsmith, S. and Crawford, S. The Responsive City: Engaging Communities Through Data-Smart Governance. Josey Bass: San Francisco, 2014.

[7] Hand, L.C. \& Ching, B.D. "You have one friend request": An exploration of power and citizen engagement in local governments' use of social media. Administrative Theory \& Praxis, 33, pp. 362-382, 2011.

[8] Sadat, D. M-Government Implementation Evaluation in Encouraging Citizen Participation in Indonesia: A Case Study of LAPOR! Thesis. University of Manchester: Manchester, 2014.

[9] European Parliament. Mapping Smart Cities in the EU. European Parliament, Directorate General for internal policies: Brussels, 2014.

[10] Centre for Cities. What does it mean to be a smart city? http://www.centreforcities.org/blog/what-does-it-mean-to-be-a-smart-city/. 2014. Accessed 1 Dec 2015.

[11] Nam, T. \& Pardo, T.A. Smart city as urban innovation: Focusing on management, policy, and context. Proceedings of the 5th International Conference on Theory and Practice of Electronic Governance, pp. 185194, 2011.

[12] Giffinger, R., Fertner, C., Kramar, H., Kalasek, R., Pichler Milanoviü, N. \& Meijers, E. Smart cities: Ranking of European medium-sized cities. Centre of Regional Science (SRF), Vienna University of Technology: Vienna, 2007. 
[13] Gil-Garcia, J.R., Helbig, N. \& Ojo, A. Being smart: Emerging technologies and innovation in the public sector. Government Information Quarterly, 31, pp. I1-I8, 2014.

[14] Rhodes, R.A.W. Understanding Governance: Policy Networks, Governance, Reflexivity and Accountability. Open University Press: Buckingham-Philadelphia, 1997.

[15] Pierre, J. and Peters, B.G. Governance, Politics and the State. MacMillan, London, 2000.

[16] Hambleton, R. and Gross, J.S. "Global Trends, Diversity and Local Democracy", in Hambleton, R. and Gross, J.S. (eds), Governing Cities in a Global Era (Basingstoke: Palgrave), pp. 1-13, 2007.

[17] Zubizarreta, I., Seravalli, A., Arrizabalaga, S. "Smart City Concept: What It Is and What It Should Be." Journal of Urban Planning and Development, Volume 142, Issue 1, 2016.

[18] de Mello Miranda, P.R., da Cunha, M.A.V.C. \& Pugas Filho, J.M. Participation in smart cities of developing countries: Research-based practical recommendations. In J.R. Gil-Garcia, T.A. Pardo, \& T. Nam (Eds.), Smarter as the new urban agenda: A comprehensive view of the 21st century city (pp. 315-332). Springer International Publishing, 2016.

[19] Roche, S., Nabian, N., Kloeckl, K. and Ratti, C. "Are 'smart cities' smart enough?” 2013 Global Geospatial Conf., Global Spatial Data Infrastructure Association (GSDI), Quebec City, Canada, 2012.

[20] Hasan, E. Komunikasi Pemerintahan. PT. Refika Aditama: Bandung, 2005.

[21] Pasquier, M. "Government Communication," in L. Côté and J.-F. Savard (eds.), Encyclopedic Dictionary of Public Administration, [online], www.dictionnaire.enap.ca, 2012

[22] Wright, D.K. The magic communication machine: Examining the Internet's impact on public relations, journalism, and the public. Institute for Public Relations: Gainesville, FL, 2001.

[23] Olsen, J.P. Maybe it is time to rediscover bureaucracy. Journal of Public Administration Research and Theory, 16, pp. 1-24, 2006.

[24] Kushchu, I. \& Kuscu, M.H. 'From E-government to M-government: Facing the Inevitable', in the 3rd European Conference on e-Government, Ireland, pp. 253-260, 2003.

[25] Alrazooqi, M. \& De Silva, R. 'Mobile and Wireless Services and Technologies for M-Government Solution Proposal for Dubai Government', WSEAS Transactions on Information Science and Applications, Vol. 7, No. 8, pp. 1037-1047, 2010.

[26] Casalo, L.V., Flavián, C. \& Guinaliu, M. 'M-Government Initiatives at the Local Level: The Case of Zaragoza', in M-Government: An Emerging Direction in E-Government, I. Kushchu (ed.), Hershey, PA: Idea Group Publishers, pp. 233-251, 2007.

[27] Nava, A. \& Davila, I. M-Government for Digital Cities: Value Added Public Services. The Proceedings of the 1st European Mobile Government 
Conference, Mobile Government Consortium International Pub., UK., pp. 302-312, 2005.

[28] Zalesak, M. M-government: Definitions and Perspectives, 1-6. Retrieved March 10, 2011, from http://zunia.org/uploads/media/knowledge/ Zalesak.pdf, 2002

[29] OECD \& ITU. M-Government: Mobile Technologies for Responsive Governments and Connected Societies, OECD Publishing, 2011.

[30] Babbie, E. The practice of social research. Wadsworth: Belmont, 1989.

[31] Yin, R.K. Mixed methods research: Are the methods genuinely integrated or merely parallel? Research in the Schools, 13(1), pp. 41-47, 2006.

[32] Miles, M.B. \& Huberman, A.M. Qualitative data analysis: An expanded source book (2nd ed.). Sage: Thousand Oaks, 1994.

[33] Kleinhans, R., Van Ham, M. \& Evans-Cowley, J. Using Social Media and Mobile Technologies to Foster Engagement and Self-Organization in Participatory Urban Planning and Neighbourhood Governance, Planning Practice \& Research, 30:3, pp. 237-247, 2015.

[34] Mergel, I. A framework for interpreting social media interactions in the public sector. Government Information Quarterly, 30, pp. 327-334, 2013.

[35] Caddy, J., Peixoto, T. \& McNeil, M. Beyond Public Scrutiny: Stocktaking of Social Accountability in OECD Countries. Washington DC: OECD and World Bank Institute, 2007.

[36] Ratti, C. \& Townsend, A. The social nexus. Scientific American, 305(3), pp. 30-35, 2011.

[37] Torres, L., Pina, V. \& Acerete, B. E-governance developments in EU cities: Reshaping government's relationship with citizens. Governance, 19(2), pp. 272-302, 2006.

[38] Kushchu, I. Mobile Government: Emerging Direction in E-Government. IGI Publishing: New York, 2007.

[39] $\mathrm{Yu}, \mathrm{B}$. \& Kushchu, I. The value of mobility for e-government. In the Proceedings of European Conference on E-Government (ECEG 2004), Trinity College, Dublin, June 17-18 (pp. 887-899). Department of the Taoiseach, Dublin, Ireland; Reading, UK: Academic Conferences International, 2004.

[40] Cilingir, D. \& Kushchu, I. E-government and m-government: Concurrent leaps by Turkey. In D. Remenyi (Ed.), Proceedings of European Conference on E-Government (ECEG 2004), Trinity College, Dublin, June 17-18 (pp. 813-821). Department of the Taoiseach, Dublin, Ireland; Reading, UK: Academic Conferences International, 2004.

[41] Hallin, A. \& Lundevall, K. "City-User Focused Development of Mobile Services within the City of Stockholm" in Kushcu, I. (ed.) Mobile Government emerging directions in e-government, IGI Publishing: New York, pp.12-29, 2007.

[42] Bătăgan, L. Smart cities and sustainability models. Informatica Economică, 15(3), pp. 80-87, 2011.

[43] Batty, M., Axhausen, K. W., Giannotti, F., Pozdnoukhov, A., Bazzani, A., Wachowicz, M., Ouzounis, G., Portugali, Y., et al. Smart cities of the 
future. The European Physical Journal Special Topics, 214(1), pp. 481$518,2012$.

[44] Deakin, M. Intelligent cities as smart providers: CoPs as organizations for developing integrated models of eGovernment services. Innovation: The European Journal of Social Science Research, 25(2), pp. 115-135, 2012.

[45] Innes, J.E. \& Booher, D.E. Planning with complexity: An introduction to collaborative rationality for public policy. Routledge: London, 2010. 